\title{
Co-ordination Failure, Moral Hazard and Sovereign Bankruptcy Procedures
}

\author{
Sayantan Ghosal and Marcus Miller* \\ Department of Economics, University of Warwick
}

September 2, 2002

\begin{abstract}
We study a model of sovereign debt crisis that combines problems of creditor coordination and debtor moral hazard. Solving the sovereign debtor's incentives leads to excessive 'rollover failure' by creditors when sovereign default occurs. We discuss how the incidence of crises might be reduced by international sovereign bankruptcy procedures and relate this to the current debate on revising international financial architecture.

Paper prepared for Bank of England Conference on "The Role of the Official and Private Sectors in Resolving International Financial Crises", London, and for the Latin American Meeting of the Econometric Society, Sao Paolo, Brazil.

(Preliminary draft circulated for comments, please do not cite without reference to the authors.)
\end{abstract}

\section{Introduction}

Debt restructuring under the Brady plan of the late 1980s involved substantial losses for those banks lending to emerging markets as their loans were swapped into Brady bonds of lesser value. Understandably, lending to emerging markets since then has been mainly in the form of New York bonds ${ }^{1}$ which are difficult to 'restructure' in this way, Buchheit and Gulati (2002). This may be useful as a check on debtor's 'moral hazard' but it means that emerging markets are prone to financial crisis from other sources such as creditor panic or exogenous shocks to debt service capacity, as the current Latin American debt crisis demonstrates. Evidently, analysing why financial crises occur involves examining the behaviour of both creditors and debtors.

In the literature on financial crisis, two problems are commonly identified, failures of creditor co-ordination and debtor moral hazard - with greater attention given to the former.

\footnotetext{
*Acknowledgements: For his comments, we are grateful to David Vines and for technical assistance to Pongsak Luangaram of the ESRC Centre for the Study of Globalisation and Regionalisation, University of Warwick. Financial support from the ESRC, under project No. R000239216 'Moral Hazard and Financial Institutions', is gratefully acknowledged.

${ }^{1}$ Many of these are the Brady bonds that were accepted in place of bank loans.
} 
In their explanation of bank runs, for example, Diamond and Dybvig (1983) demonstrated the possibility of multiple equilibria in financial markets, taking as given the structure of demand deposit contracts (i.e. the right of depositors to withdraw on demand). To help select the "good" equilibrium, three mechanisms were discussed - deposit insurance, the provision of liquidity and the suspension of convertibility. In the context of crises affecting emerging market bonds, similar proposals have recently been made. Stanley Fischer (1999), Radelet and Sachs (1998) and Truman (2001), for example, have emphasised official provision of liquidity; while Krugman (1998) called for capital outflow controls to protect East Asian currency (i.e. a suspension of convertibility). There has not been much talk of explicit insurance, Soros (1998) and Jeanne (2001) being exceptions. An additional possibility that has been widely discussed is revising the nature of sovereign debt contracts themselves: Eichengreen and Portes (1995), Buchheit and Gulati (2000) and Taylor(2002), for example, have advocated the insertion of collective action clauses (via the use of 'exit consent' swaps, if necessary).

Such proposals to solve the creditor coordination problem may be criticised for failing to take into account how they sovereign debtor incentives. Barro $(1998, \mathrm{p} .18)$, for example, suggests that bail-outs may increase the probability of sovereign default: "bailouts increase 'moral hazard' by rewarding and encouraging bad policies by governments and excessive risk-taking by banks" he writes. ${ }^{2}$ Writing from the Institute for International Finance, William Cline (2000) expressed the view of many creditors when he argued "any international arrangements that convey the impression that default is painless will tend to depress capital flows to emerging market economies. Essentially, a default-friendly international regime deprives international lender of their quasi-collateral: heightened economic difficulty for the defaulter."

Typically, solutions to the moral hazard problem have been considered in a separate strand of the literature where reputation is used as the key incentive mechanism to regulate the debtor's moral hazard problem. In Bulow and Rogoff (1989a), for example, a Rubinstein bargaining model with trade sanctions is used as a punishment mechanism to prevent strategic default. ${ }^{3}$ As their model assumes a single creditor is bargaining with the sovereign debtor, creditor coordination problems are assumed away. Moreover, the use of reputation as an incentive mechanism needs to be qualified by the fact that the punishment phase of the equilibrium strategy (a) may fail to satisfy renegotiation proofness and (b) be of limited threat in the case of a small open economy (as in Bulow and Rogoff (1989b).

We believe that a convincing treatment of sovereign debt crises and their resolution needs to combine issues of creditor co-ordination and debtor incentives in a consistent framework. In this paper, we develop such a framework. It implies that bail-outs do not solve the underlying causes of a sovereign debt crisis; and has the property that the market equilibrium

\footnotetext{
${ }^{2}$ With reference to $\$ 42$ billion package for Brazil, for example, Barro asks: "How did the Brazilians qualify for this support? They did so mostly by not exercising sound fiscal policies. If their policies had been better, they would not be in their current difficulties and would not qualify for IMF money". After further discussing the bailouts for Mexico and Russia, he concluded "the IMF might consider changing its name to the IMHthe Institute for Moral Hazard".

${ }^{3}$ Alternatively, Kletzer and Wright (2000) appeal to reputational arguments as a way of checking moral hazard.
} 
needed to provide the right incentives is excessively prone to financial crisis, cf. Jeanne (2001). Are there ways of improving on the equilibrium market outcome? We propose a international bankruptcy procedure as ex-ante commitment device that involves (a) ensuring partial contractibility of sovereign debtor's payoffs, (b) temporary suspension of convertibility in a "discovery" phase and (c) ex-post transfers. This mechanism incorporates features of the two principal proposals to resolve sovereign debt crisis currently under consideration, namely revising bond contracts to include collective action clauses (John Taylor, 2002) or a court-ordered bankruptcy procedure (Anne Krueger, 2002) discussed further in the next section. In this respect, our proposals differ substantially from those of Jeanne (2001) where solving the creditor coordination problem has no impact on the debtor's incentive problem and leads him to recommend a 'crisis insurance fund' which bails out all governments facing a rollover crisis, conditional on fiscal adjustment.

The paper is structured as follows. The next section contains a brief account of recent proposals for improving the international financial architecture, in particular the Sovereign Debt Restructuring Mechanism (SDRM) advocated by the IMF and collective action clauses recommended by the US Treasury. The analysis begins with a canonical two-player game of creditor coordination where neither creditor can make a credible commitment not to play a grab race, even when shocks are temporary. The criterion of risk dominance is briefly considered as a principle of selection between the multiple equilibria. Next we present a generic model of debtor moral hazard, where the sovereign debtor cannot credibly (or verifiably) commit to putting in effort ex-ante due to either sovereign immunity or non-contractibility of debtor payoffs; nor can he commit to ex-post bargaining in the event of default. Then we examine how the equilibrium selection in the creditor coordination problem interacts with the sovereign debtor's incentives and show that solving the sovereign debtor's incentive problems requires excessive 'project termination' by creditors when sovereign default occurs. Lastly, we consider potential improvements involving either SDRM or changes to contracts.

Various ways that issues of moral hazard and collective action can be combined, on the assumption that both creditors possess identical information and that there is a first mover advantage to quitting if the debtor defaults, are shown in Table 1 which indicates the cases that are examined in detail below.

Table 1: Creditor co-ordination and moral hazard: Various cases

\begin{tabular}{|l|l|l|l|}
\hline & No moral hazard & $\begin{array}{l}\text { Moral hazard } \\
\text { without haircut }\end{array}$ & $\begin{array}{l}\text { Moral hazard } \\
\text { with haircut }\end{array}$ \\
\hline $\begin{array}{l}\text { Temporary shock } \\
\text { (Illiquidity) }\end{array}$ & $\begin{array}{l}\text { Rollover } \\
\text { (Section 3) }\end{array}$ & $\begin{array}{l}\text { Rollover } \\
\text { (Section 4) }\end{array}$ & $\begin{array}{l}\text { Rollover \& } \\
\text { Write-down (Section 4) }\end{array}$ \\
\hline $\begin{array}{l}\text { Permanent shock } \\
\text { (Insolvency) }\end{array}$ & $\begin{array}{l}\text { Rollover \& } \\
\text { Write-down }\end{array}$ & $\begin{array}{l}\text { Rollover \& } \\
\text { Write-down }\end{array}$ & $\begin{array}{l}\text { Rollover \& } \\
\text { Write-down }\end{array}$ \\
\hline
\end{tabular}

The co-ordination game studied in Section 3 involves a pure liquidity crisis driven by temporary exogenous shocks where the appropriate solution for both creditors is to roll over their lending, see top left corner of Table 1. If the shocks are permanent and large enough to imply insolvency, this will change the payoffs available to creditors who roll over as they will have to take a write-down (see lower left); but, so long as the 'continuation value' lies 
sufficiently far above 'liquidation value', the essential structure of the co-ordination game is unchanged - though it is not examined in detail in this paper. (For corporations in default, where assets of considerable value may be attached, shrinking continuation values typically lead to a prisoner's dilemma where quitting becomes a dominant strategy, Jackson (1982): ${ }^{4}$ but for sovereigns, one may continue to use the co-ordination game framework on the ground that there are typically not many assets that may be attached by creditors.)

When we consider debtor incentives in Section 4 , it is with temporary exogenous shocks. Where bad effort leads to temporary default but not insolvency, there will be no haircut if both creditors roll over, see second column. More generally, however, bad effort will lead to a haircut, as shown in the top right, although to preserve the structure of the co-ordination game, the size of the haircut must not be too large.

\section{Sovereign debt restructuring: Two mechanisms}

\subsection{Collective action clauses in bond contracts}

After the Mexican crisis of 1994/5, the Deputies of the G-10 (Group of Ten Report, 1996). made a number of recommendations to facilitate crisis management. As regards liquidity provision, for example, they suggested that the IMF should 'lend into arrears' for countries whose domestic policies were deemed acceptable. For the private sector, they commended changes to contractual provisions covering sovereign debt (so as to allow for the collective representation of bondholders for supermajority voting on changing the terms and conditions of the debt contract: and for sharing of proceeds among creditors). Such ideas found academic support in the work of Eichengreen and Portes (1995) who recommended a creation of a Bondholders Council to help negotiate debt recontruction. But markets have proved very slow to respond. To date, only two sovereign debtors have incorporated such clauses in their foreign currency liabilities, but these are the UK and Canada and not the emerging market debtors for whom the recommendation was intended - probably because of a signalling problem (Eichengreen, 1999).

The increasingly desperate case of Argentina has re-opened the debate on sovereign debt restructuring. ${ }^{5}$ Thus in April 2002, John Taylor (2002) has, on behalf of the US Treasury, argued forcefully for the inclusion of collective action clauses in the emerging market debt. To help overcome the problem of transition, the US Treasury proposed adding substantial "carrots and sticks" as incentives to change. (Carrots could include lower interest rate charges when borrowing from the IMF; and further financial inducements to carry out bond swaps on the existing stock: as a stick, the insertion of such clauses could be made a precondition of seeking an IMF program.) To tackle problems of asset diversity, it was proposed that such clauses could be included in bank debt as well. As for problems of aggregation across creditor classes, it was proposed that disputes between creditors could be handled in an arbitration

\footnotetext{
${ }^{4}$ Baird et al. (1994, p.201), on the other hand, are somewhat sceptical of using the prisoner's dilemma framework, arguing that "bankrupcy law may not have to contend with a common pool problem at all".

${ }^{5}$ The sovereigns involved in the 1997/8 financial crisis in East Asia were not substantial debtors (at least ex ante): the debt was largely private and so in principle involved issues of corporate debt restructuring.
} 
process provided for in the contracts themselves. ${ }^{6}$

In their subsequent press release outlined principles for crisis management in emerging markets, the leaders of six private sector groups have acknowledged that "the use of of collective action clauses in individual sovereign debt contract would introduce a useful element of suppleness into the system", EMCA et al $(2002$, p.1), and indicated that efforts are being made to get an industry consensus on the most appropriate changes in sovereign debt documentation.

\subsection{A sovereign debt restructuring mechanism}

In the wake of the Mexican crisis, Jeffrey Sachs argued that sovereigns needed the basic protections available to corporate borrower and proposed an international bankruptcy court for sovereign debt restructuring. Rogoff and Zettelmeyer (2002) provide an account of this and other proposals for revising an international financial architecture to incorporate bankruptcy-style procedures.

The new Sovereign Debt Restructuring Mechanism (SDRM) first outlined by Anne Krueger in November 2001 was clearly inspired by the analogy of corporate bankruptcy procedures (Chapter 11, in particular). While collective action clauses also embody similar provisions for supermajority voting, the IMF claims that SDRM is necessary to solve the problems of aggregation and of transition (Anne Krueger, 2002, p.14).

The different paths historically taken by Britain and United States in respect of corporate debt restructuring and how this is reflected in the current debate on sovereign debt is summarised in Table2.

Table 2: Debt restructuring: Two approaches

\begin{tabular}{|l|l|l|}
\hline & Corporations & Sovereign states \\
\hline $\begin{array}{l}\text { Self-organizing } \\
\text { creditors } \\
\text { (the low road) }\end{array}$ & $\begin{array}{l}\text { 19th century Britain: } \\
\text { Majority Action Clauses }\end{array}$ & $\begin{array}{l}\text { London debt: Collective } \\
\text { Action Clauses. } \\
\text { New York Debt: Exit Consent }\end{array}$ \\
\hline $\begin{array}{l}\text { Court-ordered } \\
\text { restructuring } \\
\text { (the high road) }\end{array}$ & $\begin{array}{l}\text { 20th century USA: } \\
\text { Chapter 11 Bankruptcy }\end{array}$ & $\begin{array}{l}\text { Sovereign Debt Restructuring } \\
\text { Mechanism/International } \\
\text { Bankruptcy Court }\end{array}$ \\
\hline
\end{tabular}

This historical summary may suggest that collective action clauses and court-ordered procedures are substitutes. But commentators such as Buchheit and Gulati (2002) who argue that the global economy should now follow the lead of the London bond market in adopting collective action clauses, might note that London market has subsequently gone on to develop court-ordered bankruptcy procedures analogous to the US Chapter 11. This suggests that the mechanisms may be complementary (Miller, 2002). It may be easier in the short run to solve the transition problem of modifying bond contracts than it is to revise the

\footnotetext{
${ }^{6}$ An alternative suggestion from Morgan Chase and Co. is that of a two-step bond swap where the first step is designed designed to achieve uniformity of claim, and the second step is the actual restructuring, Bartholomew, Stern, and Liuzzi (2002).
} 
IMF Article of Agreement. But there may be advantages in having explicit sovereign debt restructuring mechanism.

Both self-organising creditors and and international bankruptcy procedure are ways of creating commitment devices which help to prevent and resolve sovereign debt $\mathrm{crisis}^{7}$. To focus on issues of creditor co-ordination and debtor's moral hazard, the simple model of sovereign debt that follows abstracts from the aggregation and transition problems which play such an important role in the current debate. But it suggests that sovereign bankruptcy procedures combined with IMF-style conditionality can better achieve the commitment needed than would collective action clauses inserted in bond contracts.

\section{Creditor co-ordination without moral hazard}

\subsection{Nash equilibria}

Take the case of a sovereign embarking on a bond-financed investment project, costing $K$, which lasts only two periods. All the finance is supplied by two investors, investing $b$ each, who are promised a return of $r$ in the first period and $(1+r)$ in the second period. So long as resources available cover these payments (i.e. cash flow in period 1 is greater than $2 r b$ and cash flow in period 2 is greater than $(1+r) 2 b)$, all is well and the project will run to completion.

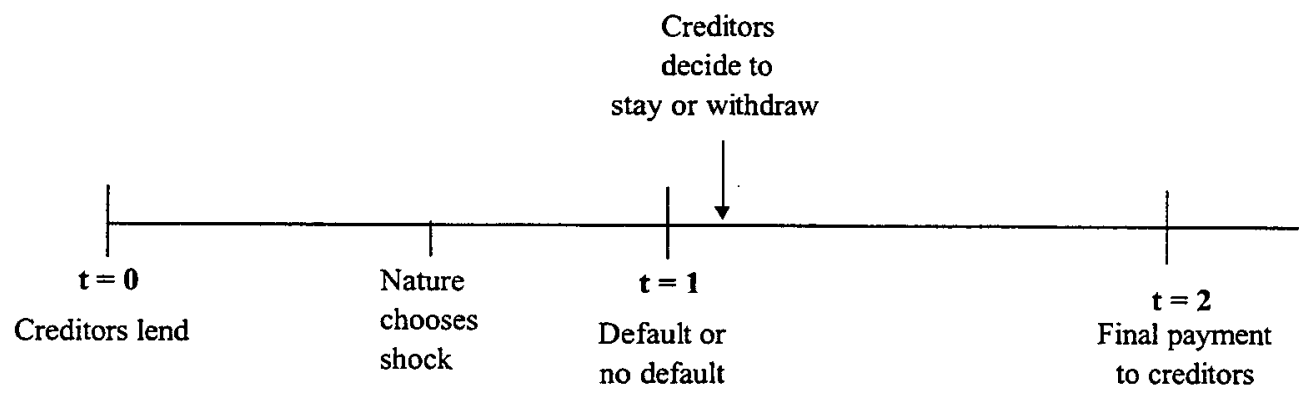

Timeline of events: Liquidity shocks

Consider what happens if an unanticipated, exogeneous shock ('bad luck') lowers the capacity to pay in period one below the amount that is due to bond holders under their contract. If it is strictly a shock to liquidity, which is what we assume in this section, then

\footnotetext{
${ }^{7}$ There is a further issue of which will work better, self-organising creditors or an international bankruptcy procedure. This requires a model with (a) heterogenous creditors (i.e. different preferences, forms of sovereign debt), (b) assymetric information about debtor type which hinder or may even prevent transition to a different regime. Again we plan to cover thius issue in future work.
} 
project net worth will be unchanged. One example might be where a country is hit by contagion and the funds earmarked for debt service are suddenly withdrawn (as for Korea in 1998); another would be a sovereign debtor in a 'credit chain' forced into default by delays in payment by its creditors. Since failure to comply with the terms of the debt contract constitutes technical default, each creditor is entitled to accelerate its claim, demanding the capital sum as well as the current coupon owed in period 1 , i.e. technical default makes the debt 'callable' in period 1 and exposes the sovereign to the risk of a liquidity crisis. (Acceleration of the claim in this way normally requires a minimum percentage of creditors to act, say 25\%: but in our two-creditor model, one is enough.)

The co-ordination game facing the two creditors is shown in Table 3 below where the actions of Creditor 1 (quit, stay) are indicated by rows 1 and 2 respectively; likewise for Creditor 2 by the columns. In the cells showing the resulting payoffs, those for Creditor 1 are given first. (The significance of $L$, the legal costs of accelerating one's claim, are discussed below.)

Table 3: How Payoffs depend on Creditor Co-ordination

\begin{tabular}{|c|c|c|c|}
\hline & & \multicolumn{2}{|c|}{ Creditor 2} \\
\hline & Actions & QUIT & STAY \\
\hline Creditor 1 & QUIT & $\bar{Q} / 2-L \quad \bar{Q} / 2-L$ & $(1+r) b-L$ \\
\hline & STAY & $\bar{Q}-(1+r) b \quad(1+r) b-L$ & $(1+r) b \quad(1+r) b$ \\
\hline
\end{tabular}

Symbols used and key assumptions made in determining the payoffs are as follows. First, if either creditor accelerates its claim, the project will end (i.e. there is a minimum level of resources $K_{1}<K$ required for continuation, and $\left.(1+r) b>K-K_{1}\right)$ where $\bar{Q}<K$ is the recovery amount if the project is terminated in period 1 . Second, the creditor who accelerates when the other does not, reckons to recover initial investment $b$ plus interest $r b$ minus the privately borne legal costs of quitting $L$ - leaving the other creditor with the residual, $\bar{Q}-(1+r) b$ as in a grab race for a firm's assets where liquidation allows the first mover to exit without much loss of value but liquidation is costly for other creditors. When both creditors quit, they split the expected recovery amount equally between themselves. (Most bargaining solutions support this assumption, including those of Nash and Kalai Smorodinsky.)

Third, we assume that unpaid interest is rolled-up and added to the coupon in period 2 , so there is no loss of value to the bondholders if the project continues. If both creditors decide to stay, the payoffs are as shown in the bottom right cell.

As is evident after normalising the payoffs (see table 4, where $1>\varepsilon>0>\delta$ ), this coordination game has three Nash equilibria, two in pure strategies (Stay, Stay) with unit payoffs and (Quit, Quit) with zero payoff and a third in mixed strategies where each creditor quits with probability $q=\frac{1-\varepsilon}{1-\varepsilon-\delta}$.

The payoffs of the normalised game are shown in Figure 1 together with three equilibria indicated at $\mathrm{A}, \mathrm{B}$ and $\mathrm{C}$. Pure strategy equilibrium represents a total coordination failure and the mixed strategy equilibrium $B$ represents a partial coordination failure. How is one to select between these equilibria? One possible answer is that the equlibrium is selected by sunspots. Sunspots are random, payoff-irrelevant states of nature which are publicly 
Table 4: Normalised expected, discounted payoffs for the co-ordination game

\begin{tabular}{|c|c|c|c|}
\hline & & \multicolumn{2}{|c|}{ Creditor 2} \\
\hline & Actions & QUIT & STAY \\
\hline Creditor 1 & QUIT & $\begin{array}{ll}0 & 0\end{array}$ & $\varepsilon \quad \delta(<0)$ \\
\hline & STAY & $\delta(<0)$ & 1 \\
\hline
\end{tabular}

observed and are used by creditors to coordinate their expectaions and actions (see, for instance, Jeanne (2002), Peck and Shell (forthcoming)). Consequence of this approach is that sovereign debt crisis occur with positive probability: but the probability is entirely independent of the underlying economic fundamentals (an aspect which Morris and Shin (1998) criticise). A more satistactory theory of which equilibrium will be chosen lies, we believe, in the need to provide appropriate incentives for the debtor. ${ }^{8}$ Before this approach is developed in the next section, consider the criterion of risk dominance.

\subsection{Risk Dominance}

In this subsection, we use the criterion of risk dominance, originally proposed by Harsanyi and Selten (1984), to determine which of the two pure strategy equilibria will be selected. Let $\alpha$ and $1-\alpha$ be the probabilities that player 1 attaches to the other player quitting and staying, respectively. Then expected payoffs to quitting and staying for player 1 are $\varepsilon(1-\alpha)$ and $1-(1-\delta) \alpha$. The condition for quitting to be strictly risk dominant (i.e. $\varepsilon(1-\alpha)$ $>1-(1-\delta) \alpha)$ is that $|\delta|>1-\varepsilon$. Thus quitting is risk dominant when the the gain to being the first mover is the creditor grab race is relatively large.

Assume that the pool of potential creditors includes some vultures who have access to a superior liquidation technology. (They may have lower legal fees and/or ways of accessing the overseas assets of the sovereign debtor.) Could it be a risk dominant strategy to sell to the vultures? The revised payoffs are shown in Table 5 below.

Table 5: Payoffs when vultures are present

\begin{tabular}{|c|c|c|c|}
\hline & & \multicolumn{2}{|c|}{ Creditor 2} \\
\hline & Actions & SELL & STAY \\
\hline Creditor 1 & SELL & $\begin{array}{ll}\widehat{\varepsilon} & \widehat{\varepsilon}\end{array}$ & $\widehat{\bar{\varepsilon}} \quad \widehat{\delta}(<0)$ \\
\hline & STAY & $\widehat{\delta}(<0) \quad \widehat{\varepsilon}$ & 11 \\
\hline
\end{tabular}

Note that since one gets more by selling to a vulture fund than by terminating the project, $\widehat{\varepsilon}>\varepsilon$ and assuming that not seling to a vulture cannot improve a creditor's prospects, $\widehat{\delta} \leq \delta<0$. Given these payoffs, it turns out that selling to a vulture is risk dominant if $|\widehat{\delta}|>1-2 \widehat{\varepsilon}$.

\footnotetext{
${ }^{8}$ Others commentators (Stiglitz, 2002a) believe that asymmetric information between creditors is main reason for excessive default, rather than the problem of debtor's moral hazard. In a complete analysis, it should be possible to combine asymmetric information problems with those of debtors moral hazard.
} 
Figure 1: Discounted expected payoff in period 1: The creditor co-ordination game (with normalised payoffs)

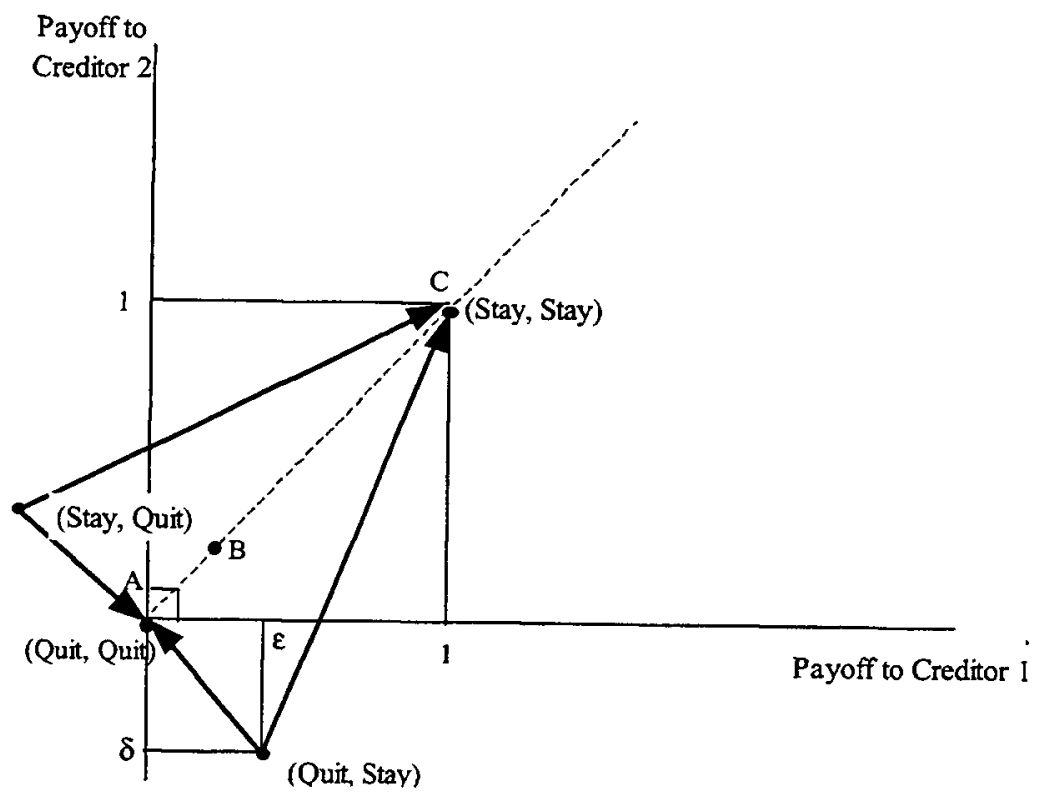

Comparing the two inequalities $|\delta|>1-\varepsilon$ and $|\widehat{\delta}|>1-2 \widehat{\varepsilon}$ it is evident that quitting is more likely to be risk dominant when the pool of creditors includes a few vultures.

Before we end this sectiion, it worth pointing out that the above analysis of creditor coordination can alos be extended to the case where the shock on the country's fundamentals is not temporary. In particular, conditional on default, there may be incomplete information and disgrement within creditors abo9ut whether the shock is temporary or permamnent. In this case, (see Ghosal and Miller (2002)), it is possible to show that, at equilibrium, there is inefficient termination of the project as well.

\section{Sovereign borrowing with moral hazard}

In solving the problem of creditor coordination, we have so far ignored the issue of sovereign debtor's moral hazard. This makes the analysis incomplete as any proposed solution to the creditor coordination problem will alter the incentives of the sovereign debtor. If the probability of project termination is reduced to zero, for instance, this may have the perverse consequence of actually increasing the possibility of sovereign debt crises, Barro (1998), as a 
sovereign debtor may use the money borrowed from creditors unwisely. Indeed, it is possible (as established formally below) that a positive probability of termination may be needed to solve the moral hazard problem.

The model of debtors moral hazard developed here is of a small open economy where, as in Bulow and Rogoff (1989b), the interest rate at which the sovereign can borrow in world markets is fixed. (For simplicity, dynamic interactions between creditors and sovereign debtors such as those involved in reputation models are ignored ${ }^{9}$.) Assume as before that the sovereign issues debt in period 0 which promises an interest coupon in period 1 and repayment the capital sum together with a second interest coupon in period 2 . But before the first coupon becomes due, there are two events that may lead to default. First the debtor has to choose a level of effort, either good and bad; and second an independently determined negative shock arrives with probability $p$. Since we are still looking at liquidity crises, bad effort in this context involves condoning (or causing) cash flows to be temporarily diverted so that debt interest due cannot be paid on time. (It might involve those in power shipping cash overseas in a flight of capital which leads to default, for example.) We assume that either bad effort or a negative exogenous shock is sufficient to cause default but which of these is not immediately evident. If the causes of the technical default is revealed fairly soon ('early') i.e. before creditors have to decide before stay or withdraw, the delay is not significant. But the problem of debtor's moral hazard arises when creditors have to decide whether to stay or withdraw before revelation takes place.

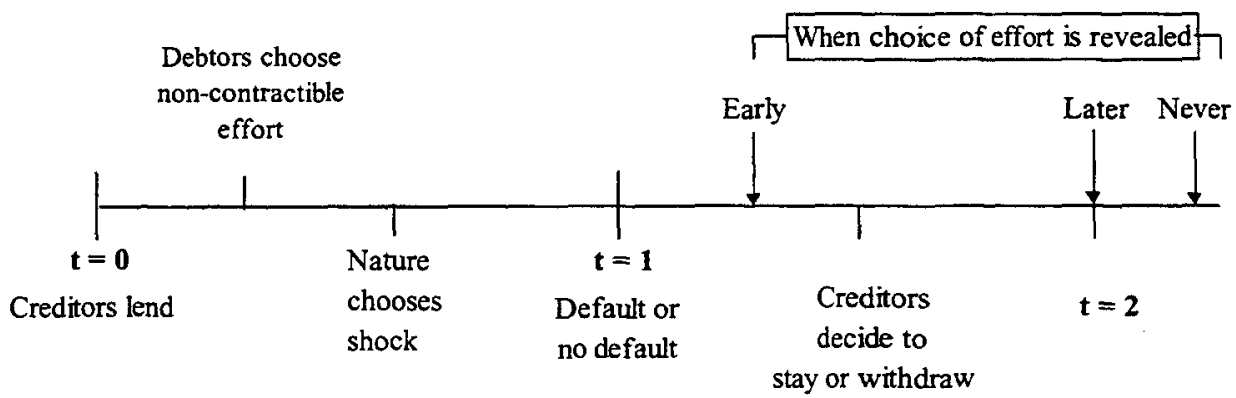

Figure 2: Timeline of events

As shown in Figure 3 below, there are four possible out-turns in period 1, where it is assumed that with good effort plus good luck the coupon can be paid, but not otherwise.

We assume that creditors are able to distinguish between a default caused by bad luck plus bad effort and defaults due to only one of these factors; but they are unable to distin-

\footnotetext{
${ }^{9}$ There is no loss of generality in doing so as Bulow and Rogoff (1990) have shown that reputation may not be renegotiation proof in models of sovereign debt in small open economies.
} 
Figure 3: Events prior to default or no default in period 1

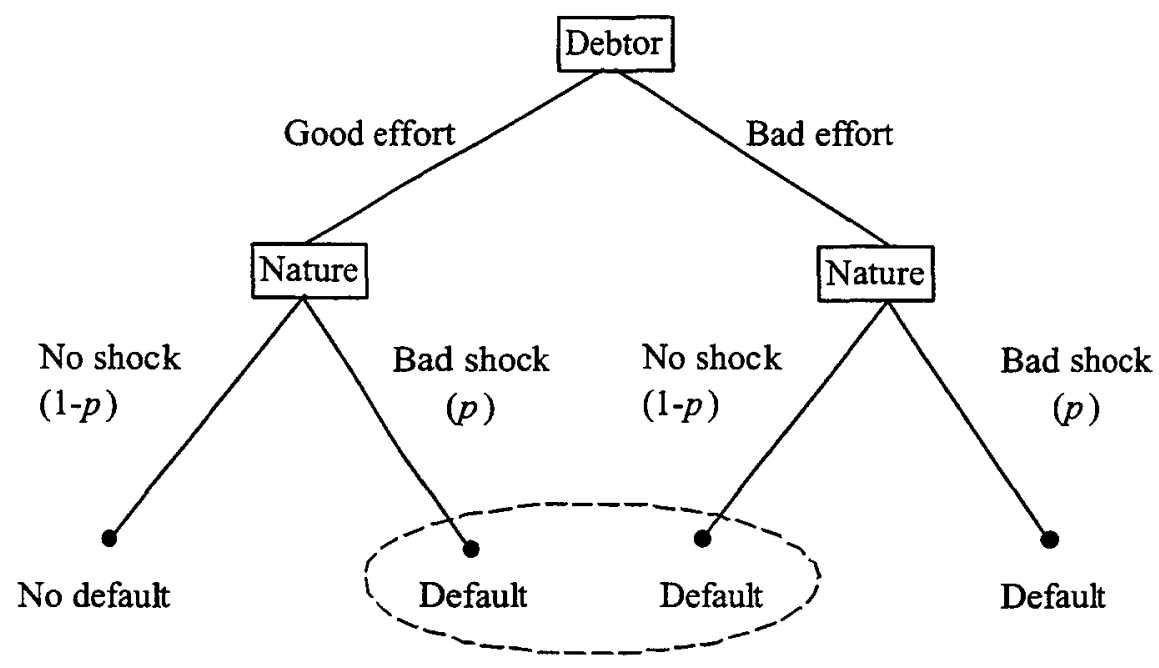

guish between cases of the latter. So, as the circle in figure 3 indicates, they are unable to distinguish between default due to a bad shock (for example, a delay in receipt of payments due to the sovereign in period 1) combined with good effort, and one due to just bad effort - with no shock ( capital flight, for example)c.

In the subgame following default, the co-ordination game facing the two creditors is shown in Table 6 below.

Table 6: How Payoffs depend on Creditor Co-ordination

\begin{tabular}{|l|l|l|l|}
\hline & & \multicolumn{2}{|c|}{ Creditor 2 } \\
\hline & Actions & QUIT & STAY \\
\hline Creditor 1 & QUIT & $\bar{Q} / 2-L \quad \bar{Q} / 2-L$ & $(1+r) b-L \quad \bar{Q}-(1+r) b$ \\
\hline & STAY & $\bar{Q}-(1+r) b \quad(1+r) b-L$ & $(1+r) b-(1-p) h \quad(1+r) b-(1-p) h$ \\
\hline
\end{tabular}

The only new elements are the continuation values if both creditors choose to stay. As before, we assume that unpaid interest is rolled-up and added to the coupon in period 2, so there is no loss of value to the bondholders from a temporary exogenous shock if the project continues. But creditors will not be paid in full if sovereign does not choose to put in good effort. Let $p$ be the probability of a exogenous shock drawn by nature and $h$ denote the hair-cut taken by creditors (due to bad effort by the debtor) ${ }^{10}$. With probability $p$, each

\footnotetext{
${ }^{10}$ While we refer to good and bad effort, the model may be interpreted such that the debtor chooses low and high risk growth strategies, for example where the latter poses the risk of a positive hair cut in period 2.
} 
debtor obtains $(1+r) b$ at $t=2$ while with probability $1-p$, each creditor suffers a hair cut, $h$, at $t=2$; therefore, conditional on the default at $t=1$, the expected payoff to each creditor at $t=2$ is $(1+r) b p+[(1+r) b-h](1-p)=(1+r) b-h(1-p))$.

Normalizing payoffs as before, the payoff matrix will have the same structure as before and therefore the set of equilibria remain unchanged. In this section, we will focus on the mixed strategy equilibrium where either creditor quits with probability $q$. Since either one leaving triggers disorderly default, the continuation probability is $1-\pi_{c}=(1-q)^{2}$ where $\pi_{c}$ is the probability of disorderly default.

What if the need to provide incentives for the debtor to put in high effort is used as a principle for selecting equilibrium? Assume that the continuation outcome, where neither quits, cannot be the part of a sub-game perfect equilibrium where the debtor chooses to put in effort (i.e. assume that a debtor, whose funding is guaranteed, will inevitably be tempted to put in low effort). By contrast, the outcome where creditors quit for sure will certainly give debtor an incentive to put in effort: but it is socially inefficient as any temporary exogenous shock will trigger a liquidity crisis. The mixed strategy equilibrium should provide some incentives the debtor: but will this be socially efficient?

\subsection{Debtor moral hazard and incentive compatible randomisation}

The source of moral hazard in our model is that the sovereign debtor has non-contractible payoffs and the incentives of the sovereign debtor are not aligned with those of the creditors. Funded by resources borrowed in the international bond markets, we assume that the sovereign debtor receives 'private payoffs' when the project terminates at $t=1$ or at $t=2$. To begin with, we assume that these payoffs are essentially non-contractible, i.e. cannot be attached by the creditors in settlement of their claims nor can the sovereign debtor make a credible commitment to transfer these payoffs to the creditors. If funds are used to subsidise a public corporation, for example, the assets of the corporation are not attachable even though the sovereign has waived immunity: so these assets would count as private payoffs. Funds transferred to private citizens fall in the same category: the added popularity of the government is not something that creditors can attach either.

We further assume that the value of these debtor payoffs depends on whether 'effort' is good or bad, where good effort implies that default only occurs with the bad exogenous shock but bad effort implies that default is inevitable. Good effort could correspond to a situation where, for instance, money is borrowed and used to promote $R \& D$ in the export sector to help the country remain internationally competitive. Bad effort might correspond to transferring borrowed money to rich people who are free to put it in tax havens overseas, exposing the country to currency risk and the budget to a loss of tax revenue. (An alternative interpretation, suggested by James Tobin, would be that good effort corresponds to properly regulated liberalisation of domestic financial markets and bad effort corresponds to un-regulated financial liberalisation. ${ }^{11}$ )

\footnotetext{
"1"The central bank, committed to honor the peg and to maintain the country's terms of trade, has to protect its reserves, It cannot be indifferent to the claims on those reserves negotiated by private parties, domestic and foreign, who ignore the social risks. An obvious precaution is to limit even to zero the net
} 
Let $u_{t}^{G}$ and $u_{t}^{B}$ denote the expected, discounted payoffs (measured at $t=1$ ) for sovereign debtor when the project is terminated at period $t, t=1,2$. We assume that $u_{t}^{G}$ and $u_{t}^{B}$ include both the residual value of the project financed by overseas borrowing net of debt service costs and also the private non-contractible benefits to the sovereign. Suppose $u_{t}^{G}<$ $u_{t}^{B}$ for all $t$. In that event, there is no solution to the debtor moral hazard problem without bankruptcy procedure because, ex ante, the sovereign debtor will always choose the bad effort even if the project is terminated in period 1 . The intermediary case, which we study below, is when $u_{1}^{G}>u_{1}^{B}$ but $u_{2}^{G}<u_{2}^{B}$. This is shown in figure 4 where $\mathrm{BB}$, the schedule showing expected payoff to bad effort, is steeper than GG which gives the expected payoff to good effort. If the probability of continuation $1-\pi$, was equal to 0 , second-period payoff would of course be irrelevant. As $1-\pi$ increases to one, however, the prospect of continuation with high private benefits makes bad effort ('shirking') more attractive.

Figure 4: Debtor moral hazard: The no-shirking constraint

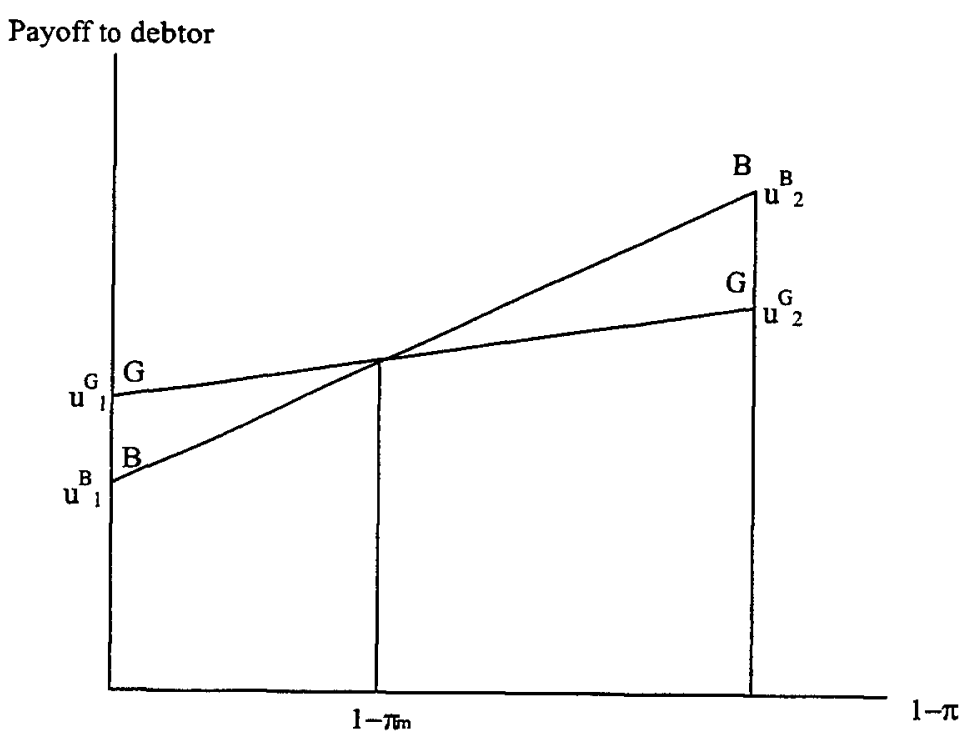

To ensure that the sovereign chooses good effort, the probability of continuation must exceed $1-\pi_{m}$ where the two schedules intersect in figure 4 i.e. there is a 'no shirking' constraint associated with debtor's moral hazard. As it is derived independently of creditor co-ordination, there is no reason why it should coincide with the continuation probability $1-\pi_{c}$ associated with the mixed strategy equilibrium for the creditors.

First, consider the case where the continuation probability generated by creditors is

indebtedness (particularly the short-term debt) in hard currency permitted any private bank." Tobin (1999, p.73) 
too high to satisfy the 'no shirking' constraint. To check moral hazard and induce effort, creditors must select the pure strategy equilibrium of disorderly default for sure. But to have the debtor apply his best efforts only to face certain default is obviously socially inefficient.

These results are summarised in Figure 5 . On the vertical axis is plotted $1-\pi_{c}$, the probability of continuation given the mixed strategy equilibrium of the creditor co-ordination game, while on the horizontal is plotted $1-\pi_{m}$, the continuation probability required for time-consistency or 'subgame perfection' on the part of the debtor. The shaded part of the figure shows the excess default probabilities relative to second best. ${ }^{12}$

Figure 5: Excessive probability of disorderly default

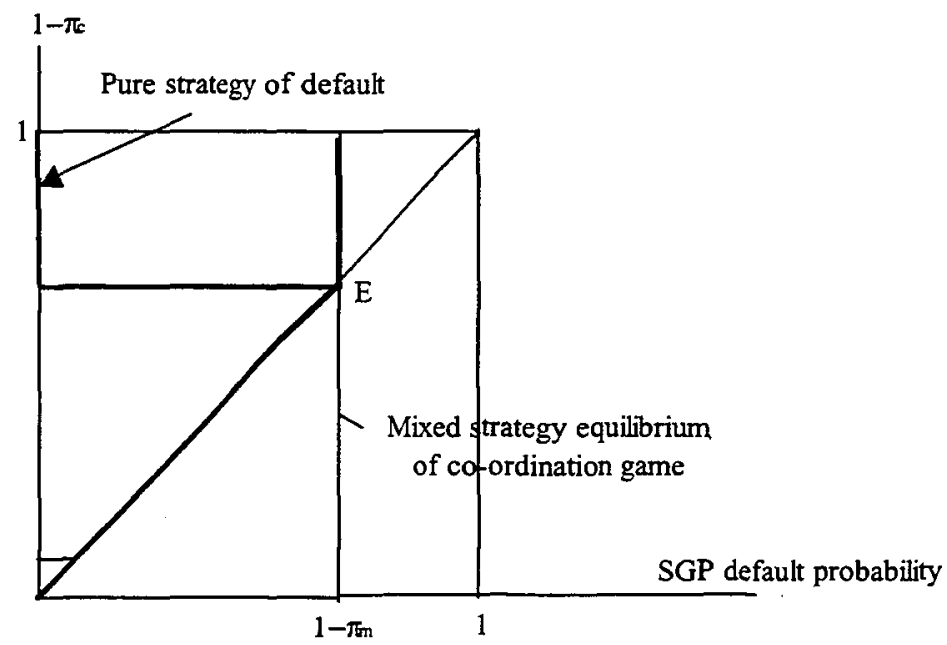

Let $1-\pi_{c}$ denote the Nash equilibrium continuation probability (NEC). Then, $1-\pi_{c}$ $=1-q^{2}=$ NEC when $1-q^{2}<1-\pi_{m}$, NEC $=0$ otherwise. Let $1-\pi_{m}$ denote the incentive compatability continuation probability (ICC). The above discussion is summarised as the following proposition.

Proposition 1 Almost always, NEC>ICC.

Proof. The truth of this proposition is evident from Figure 6.

Why providing the right incentives for the debtor implies excessive crises is indicated graphically in four-quadrant figure 6. Creditor payoffs and three possible equilibria of the

\footnotetext{
${ }^{12}$ The second best outcome, in this context, corresponds to the case where an international lender of last resort bails out both creditors for sure but only rescues the debtor with probability $1-\pi_{m}$, i.e. it practices a policy of constructive ambiguity where the probabilities are defined by the need to solve the incentive problem.
} 
co-ordination game are shown top left panel. The non-contractible payoffs to the debtor depending on whether effort is not applied are shown in the top right panel, where the maximum probability of continuation compatible with good effort, $1-\pi_{m}$, is shown on the horizontal axis (below the intersection of GG and BB at I). How does this incentive compatibility constraint affect the selection of equlibrium for creditors? Clearly it rules out equilibrium at A (stay, stay). It is, however, consistent with the mixed strategy equilibrium at $\mathrm{B}$. This can be seen using the transformation of continuation rates for individual players into continuation probability for the game as a whole (in the lower left panel) and comparing the resulting continuation probability $1-\pi_{c}$ with the incentive compatibility constraint (see the bottom right panel). The level of randomisation for creditor co-ordination is compatible with the debtor putting in effort: but there is 'too much' randomisation in that higher continuation probability among creditors would also be incentive compatible. It is, in this sense, the market equilibrium is inefficient where the excess randomisation is indicated by the shading in the diagram.

This inefficiency would greatly increase, however, if the continuation probability from the co-ordination game were to rise above $1-\pi_{m}$ (i.e. if point $B$ were to approach sufficiently close to $\mathrm{C}$ ). In that case, the only credible equilibrium consistent with debtor incentive is where both creditor quit as soon as default occurs. The excess randomisation in this case, $1-\pi_{m}$, is shown by the shaded box in the panel.

Only at the point $\mathrm{E}$ is the Nash Equilibrium randomisation equal to the incentive compatible randomisation. This leads to the conclusion that, in the absence of bankruptcy style procedures, there will almost always be excessive disorderly default in sovereign bond markets. Before considering policy iniatives to counter inefficiency, we consider briefly how premature capital liberalisation might make it worse.

\subsection{Possible perverse effects of un-regulated financial liberalisation}

Say, financial liberalisation makes it more attractive to pursue the bad effort strategy, as would be true if, for example, unregulated capital account liberalisation makes it easier to ship money out of the country into foreign tax havens rather than keeping it at home in productive investment. In this case, liberalisation would, as shown in Figure 7, generate a upward shift from BB to B'B'. As the intersection with GG moves to the left from I to I', this will reduce the incentive compatible continuation probability. If the incentive compatibility condition was still satisfied at $1-\pi_{\mathfrak{c}}$, this would, of course, have no effect on equilibrium. But if not (as in the figure), then the results are dramatic: in the face of default for any reason, only the threat of certain withdrawal will be sufficient to check debtor's moral hazard.

Is this simply a theoretical curiosum? As Tobin (1999, p.73) notes: "In the 'bailout' packages for East Asian economies, further cross-border financial liberalization was one of the conditions imposed by the IMF and the U.S. Treasury for official loans. This was a surprising requirement, given the evident facts that excessive private external short-term debt was, if not a cause of the crisis, a serious aggravation of it, and that banking and financial institutions seemed to need more regulations in several respects as well as fewer in other respects." Pressure to increase competition in financial markets may also be counterproductive in the absence of appropriate financial regulation. As Hellman, Murdock and 
Figure 6: Creditor co-ordination and debtor moral hazard

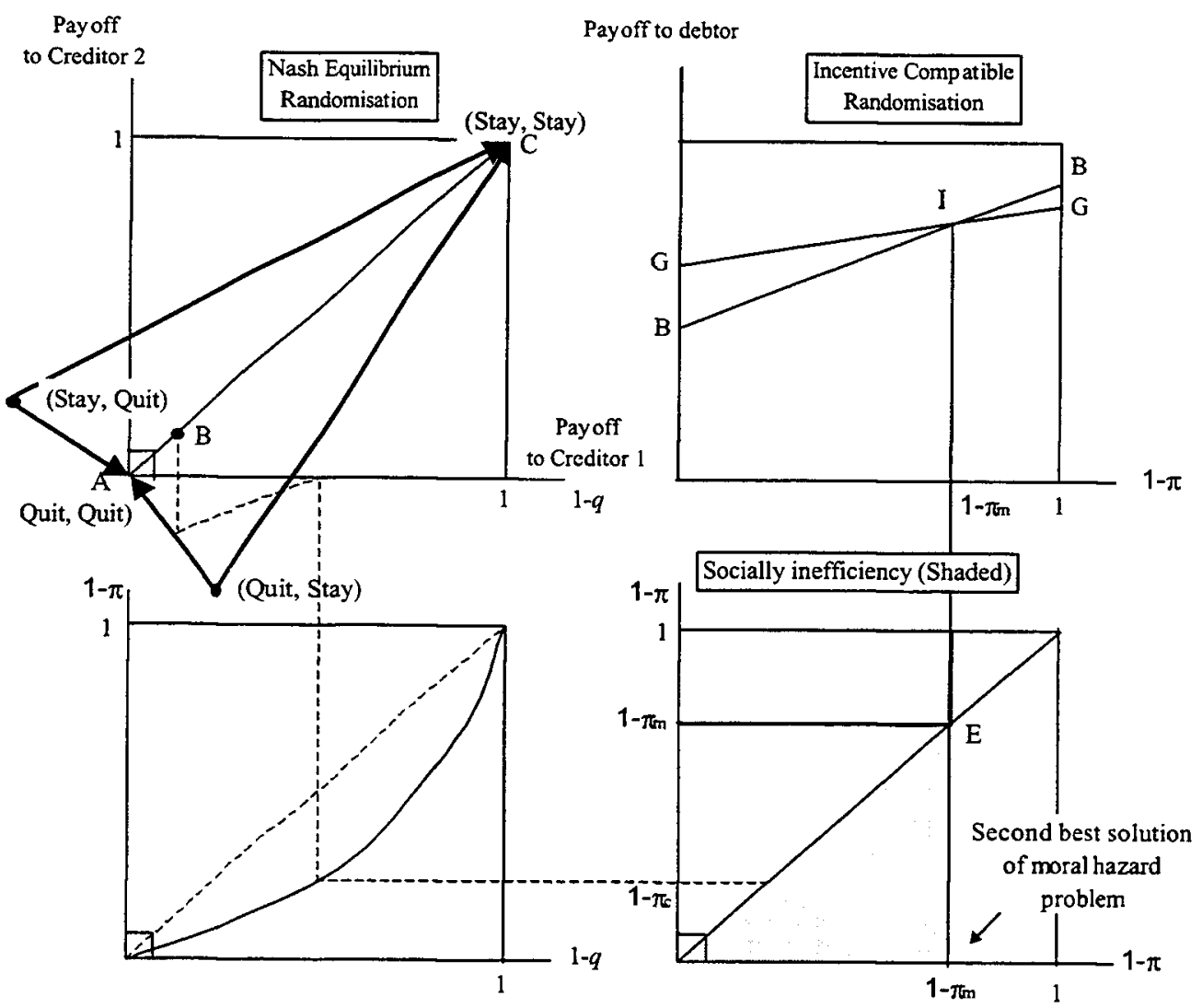


Figure 7: Possible effects of badly-designed liberalisation

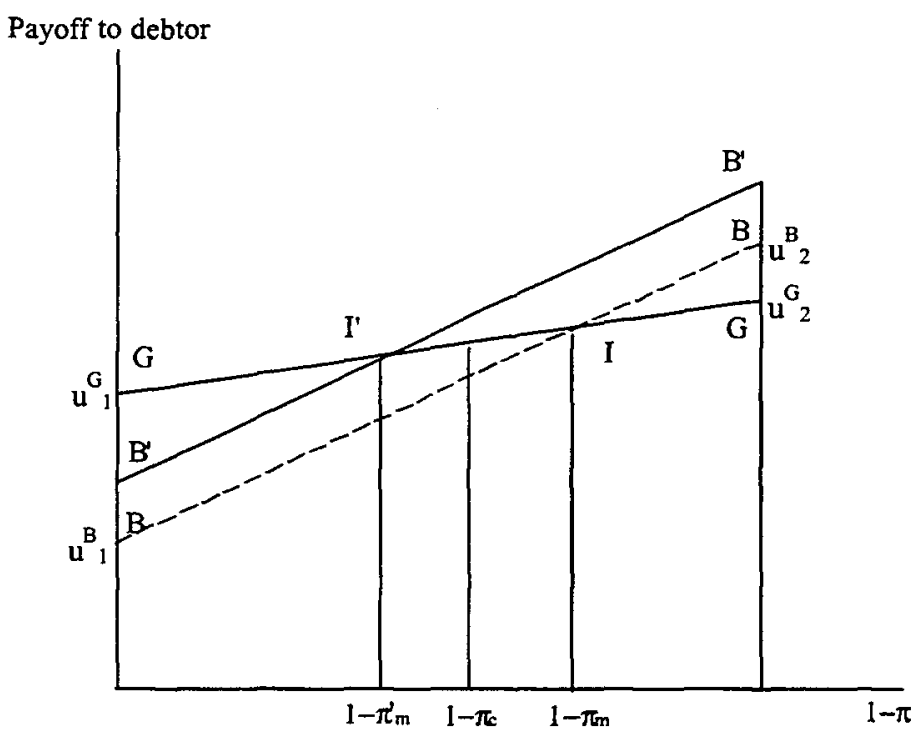

Stiglitz (2000) show, increased banking competition can lead to 'gambling' (i.e. choosing risky project with low social returns) in that case.

\section{Sovereign bankruptcy procedures as a commitment device}

We have seen that, in the absence of institutional innovation, there will be excessive disorderly default in equilibrium. Can this be reduced by institutional change?

Where creditors can exercise some legal claim over the assets of the sovereign state or its citizens in event of default, there is a good case for a bankruptcy procedure. This might involve the following elements. Ex ante, the sovereign agrees to bargaining in good faith after default, and to this end, establishes some 'contractability' on assets in favour of the creditors. This could involve waiving sovereign immunity, and agreeing, for example, that some overseas interest payments it receives could be diverted in favour of creditors as part of the bargaining process.

When a default occurs, however, the sovereign debtor is afforded protection by a temporary stay on creditor litigation. This legitimises the suspension of payments and also prevents litigation (by 'vultures') from inhibiting negotiations, Miller and Zhang (2000). Furthermore, it provides a breathing space for a 'discovery' process where efforts are made to distinguish the underlying causes of default (and to determine whether it was due to a bad shock or poor effort). If this reveals the debtor to have made appropriate effort and to be suffering from an exogenous shock, bargaining would involve the lengthening of debt maturities for temporary 
shock and some write-down for a permanent shock known to be outside the control of the debtor. But if the debtor is revealed to have made little or no effort to arrange its financial and fiscal affairs, then its payoffs are changed ex post in ways that have been agreed ex ante. It is to to make this possible that the debtor must have agreed to make some private payoffs contractible $^{13}$

Assuming the discovery phase allows creditors to discriminate between the two possible causes for default, the knowledge that such procedure is in place should reduce the moral hazard problem. This can be shown in figure 8 where the ex ante agreement to transfer funds to the creditors in period 2 in event that default is discovered to be attributable to low effort has the effect of swivelling the BB schedule clockwise and increasing the maximum continuation probability as shown for example by $1-\pi_{m}^{\prime}$.

Figure 8: Shifting the no-shirking constraint by ex ante contract

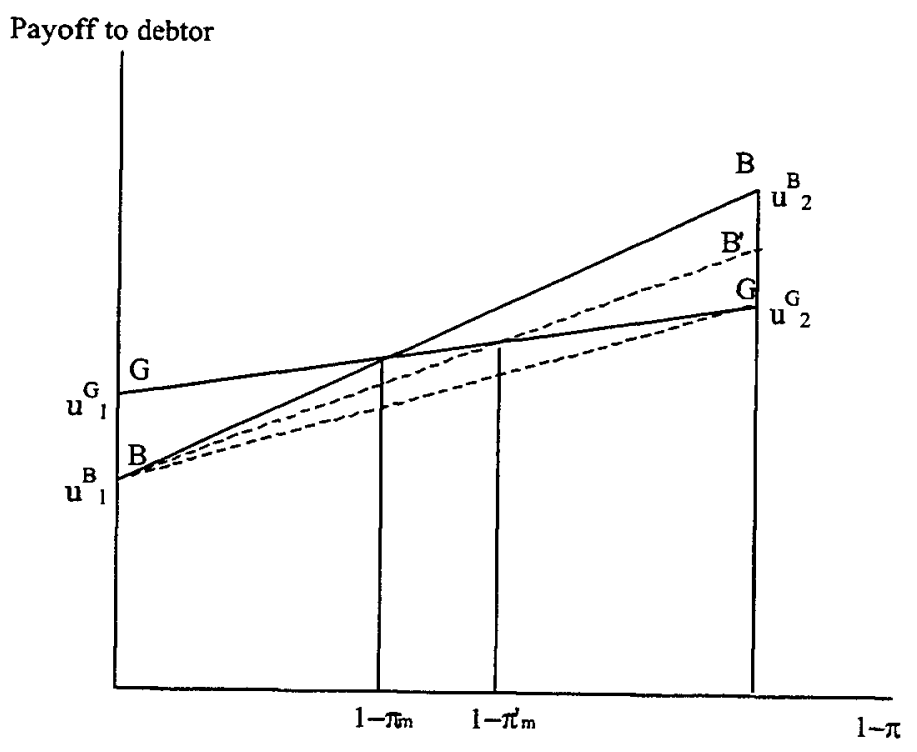

If ex ante contracting ensures that $u_{2}^{B}$ is less than or equal to $u_{2}^{G}$, as shown by the lower dotted line the figure, then the maximum incentive-compatible continuation probability shifts to one and the creditors can safely roll over their lending without fear of moral hazard. Even if the moral hazard constraint does not rise to one, but only to $1-\pi_{m}^{\prime}$ as shown in the figure, bankruptcy procedures can reduce termination probability without completely eliminating them.

\footnotetext{
${ }^{13} \mathrm{As}$, for example, when the waiver of sovereign immunity was widened to allow for claims on assets of public corporations.
} 
Before further discussing policy implications, we consider two special cases. First where the reasons for default are known as soon as it occurs, i.e without a discovery phase. In this case, there is no need for an extended bankruptcy procedure. If the default is due to an exogenous shock, liquidity can be provided right away. If the default is due to lack of effort, then the debtor's payoffs are changed ex post in ways that have been agreed ex ante. This is perspective taken by Olivier Jeanne (2001) who argues that "the institution that brings the economy the closest to the first-best is a 'crisis insurance fund' that bails out all governments with a rollover crisis conditional on the fiscal adjustment", (p.19, italics in the original). Under the proposed scheme, moral hazard is neutralized by denying bailouts to countries that have not implemented the fiscal adjustment. But as Jeanne notes, the crisis fund would probably have to be a rule-based public agency because insurance contract cannot be made contingent on fiscal effort. ${ }^{14}$

At the other end of the spectrum is the special case where the discovery phase is completely unrevealing, so the indeterminacy as to the causes of default can never be resolved. In these circumstances, the contractibility over private benefits cannot be exploited, and 'constructive ambiguity' appears to be the only solution where all defaulting debtors are bailed out with probability $1-\pi_{m}$ and the expected costs to creditors are reflected in sovereign spreads.

\section{Some policy implications}

If it is true that financing development by issuing bonds exposes emerging markets to excessive crisis, the most obvious implication is to limit the use of such instruments, Rodrik (1998). Some economists (e.g. Stiglitz, 1998, Williamson 1995 and 1999) have discussed the use of explicit inflow controls such as those used in Chile intended to change the composition of flows in favour of longer term investment rather than hot money. ${ }^{15}$ As Cordella (1998) points out, inflow controls which succeed in shifting the structure of external financing may increase rather than decrease the total volume of finance available for development: this is because "taxes on short-term capital flows by avoiding rational panics, can improve the expected returns of investments in emerging markets, and thus increase the total volume of funds entering the country", (p.6). In time of crisis, however, the use of outflow controls may well be considered, both as a way of conserving scarce foreign currency and of lowering domestic interest rates, Krugman (1998).

In discussing various mechanisms for reducing global financial instability, Rogoff (1999, p.37-8) concludes that "the main problem with the present system is that it contains strong biases towards debt finance". To mitigate this bias, he argues for a reversal of legal trends which have enabled creditors to enforce emerging markets debt contracts in industrialised country courts - effectively recommending the restoration of sovereign immunity. He repeats a recommendation made earlier, Bulow and Rogoff (1990), of 'restricting countries' ability

\footnotetext{
${ }^{14} \mathrm{He}$ also notes that "a private insurer would have strong incentives to renege the contract ex post (by not lending in the event of bad news). Even if one assumes that the private insurer can be forced by a court to lend later, it would be too late", (p. 21)

${ }^{15}$ China attracts massive FDI inflows but strictly limits other forms of external finance.
} 
to waive sovereign immunity as a means of discouraging the mediation of debt contracts in industrialized country courts", (p.38). It is acknowledged that this recommendation would lead to a contraction in the issuance of sovereign market bonds. He goes on to observe that "instituting an international bankruptcy court might be an alternative means to the same end", adding "I am assuming it would turn out to be toothless, but nevertheless would supercede domestic law."

The debate between John Taylor and Anne Krueger is, on the contrary, premised on widespread continuation of bond finance for emerging markets countries without sovereign immunity, as is our own discussion of the bankruptcy procedure - where we see an important role for a rule-governed public agency to supply a commitment mechanism which makes private payoffs accessible to the creditors ex post. It may be that the required control over the ex post behaviour of the debtor could be achieved by official "IMF conditionality" which governs the actions of the sovereign whose debt is being restructured. (Applicants for debt restructuring in the Paris Club are required as a matter of course to agree a programme with the IMF before negotiation with creditors begin.) Thus IMF programmes could play an important role in the international bankruptcy procedure described above. ${ }^{16}$ To check moral hazard, of course, it would have to be known in advance that 'conditionality' would be used to achieve the contractibility of private payoffs, i.e. the 'rules' need to be clear.

Could the required precommitment be achieved by private bond contracts? If as is customary, contracts are incomplete and involve creditors deciding what to do ex post, we believe that they are insufficient to the task. Moreover, the contracts with majority action action clauses may fail to be renegotiation proof after a discovery phase in which the debtor is effort level is confirmed to be "bad". In this case, the debtor may renege on its comitment to make ex-post transfers. In other words, a hold-up problem may ensue as now the sovereign debtor has all the bargaining power. Anticipating this, even with majority action clauses, creditors may choose to terminate the project. A SDRM backed by an international organisation, acting on behalf of the international community, can solve such a hold-up problem by making the sovereign's payoff attachble ex-post. In other words, our analysis of the recent for excess volatility leads us to choose an SDRM mechanism rather than private contracts. But two delicate issues need to be considered: whose private payoffs should be attached ex post; and to whom should responsibility for overseeing such attachment be delegated?

The former is the matter of political economy. What if, in a crisis, those responsible can exit, leaving debt for others to pay? In extreme cases, sovereign debtors may appeal to the principle of 'odious debt' where a state may justifiably repudiate obligations incurred by tyrants no longer in power (Birdsall and Williamson, 2002, and Kremer and Jayachandran, 2001). But assuming that this does not apply, is it efficient or fair to punish those who could

\footnotetext{
${ }^{16}$ How does this differ from what happens with IMF "bail-outs" where private creditors who wish to exit can do so using emergency official funding and the IMF can impose conditionality so as to secure repayment? (Jeanne and Zettlemeyer, 2000 provide evidence that official funding is almost always repaid.) If this is known ex ante, is it not as if creditors can secure commitment from the debtor? Yes but, given the possibility of exit, they do not have the appropriate incentives: there is a problem of investor's moral hazard where private creditors fail to monitor. The bankruptcy procedures advocated by Anne Krueger explicitly prevent creditor exit so as to avoid this problem.
} 
not exit? It appears that in Argentina, for example, rich and well-informed citizens were able to take their capital out of the country, thus avoiding the precipitate depreciation of the peso. ${ }^{17}$ If rich private residents have made enormous capital gains on exporting dollars from the country - now in default for lack of dollars to service its debt - should they not participate in the cost of clearing up the ensuing chaos? Capital gains on private dollars overseas in Switzerland are untaxable until realised. Could the state not demand payment of capital gains tax on the assets "marked to market", for example; or in extremis enforce repatriation in order to ensure the realisation of capital gains (and a massive inflow of dollars)?

Even if one could think of such devices for making private payoffs contractible, what public agency would be prepared to implement them? The IMF is willing to contemplate inflow controls and standstills as part of an SDRM; but outflow controls and enforced repatriation are, to put it mildly, inconsistent with its normal practices and procedures.

\section{Conclusion}

Solutions to the problem of creditor co-ordination in sovereign bond markets are subject to a moral hazard contraint: they must give debtors the right incentives to service their debts. In a model of sovereign illiquidity where there is a creditor co-ordination game with three equilibria, we find that this incentive contraint rules out the no crisis equilibrium. It selects either the mixed strategy equilibrium or the pure strategy where all creditors quit, depending on how severe the incentive problem is. Since, in general, the rate of termination is higher than strictly necessary for incentive purposes, this leads to a search for mechanisms to improve bond market efficiency. We discuss a bankruptcy procedure involving temporary stay on creditor litigation and discovery process for determining the underlying causes of default. A key element of the procedure is that when the sovereign debtor in default is found to have made little or no effort, its private payoffs will be reduced ex post. To provide the right incentives, it is crucial that the mechanism for doing this should have been agreed ex ante, as would be true if a ruled-governed public agency is involved.

Can privately issued bond contracts achieve the same result? Assume that the inclusion of collective action clauses in sovereign bond contracts can be implemented by bond swaps. Assume too that aggregation across different debt instruments can be effected by two-stage bond swaps. Nevertheless the degree of commitment achievable with such contracts seems inadequate for the purpose. They are not re-negotiation proof. Some observers have suggested instead a return to sovereign immunity (Bulow, 2002) - as a way of making clear to creditors the degree of moral hazard involved: let the buyer beware. For our part, we believe that the institutional approach to sovereign debt restructuring proposed by the IMF is, in

\footnotetext{
${ }^{17}$ "It's true that Argentina has large external debt interest payments. But it also has substantial external debt income" According to Michael Gavin of UBS Warburg: "The net external interest burden is actually quite modest, external debt payments were $\$ 12.5$ billion in 2000 or about $4 \%$ of GDP." But Argentines earned an estimated $\$ 6.4$ billion or just over $2 \%$ of GDP. For that the country should pay the price of default? (Smalhout, 2001). Informal estimates made at the IIE suggested that private external assets might amont to around $\$ 150$ billion dollars, i.e. they might even match the public debt that has caused the collapse of the peso.
} 
principle, capable to increase bond market efficiency. What the rules should be, and whether the IMF as currently constituted is the appropriate public agency, are issues to be discussed.

\section{References}

[1] Barro, Robert (1998). 'The IMF Doesn't Put Out Fires, It Starts Them', Business Week (December 7), p. 18.

[2] Bartholemew, Ed, Ernest Stern and Angela Liuzzi (2002). 'Two-step Sovereign Debt Restructuring', Mimeo. New York: JP Morgan Chase and co.

[3] Birdsall, Nancy and John Williamson (2002). Delivering on Debt Relief: From IMF Gold to a New Aid Architecture, Washington, D.C.: Institute for International Economics.

[4] Bulow, Jeremy (2002). 'First World Governments and Third World Debt: A Bankruptcy Court for Sovereign Lending?', presented at the Brookings Panel, April 4-5. (Forthcoming in Brookings Papers on Economic Activity).

[5] Bulow, Jeremy, Kenneth Rogoff (1989a). 'A Constant Recontracting Model of Sovereign Debt', Journal of Political Economy, vol. 97(1), pp. 155-78.

[6] Bulow, Jeremy and Kenneth Rogoff (1989b). 'Sovereign Debt: Is to Forgive to Forget?', American Economic Review, vol.79(1), pp. 43-50.

[7] Bulow, Jeremy and Kenneth Rogoff (1990). 'Cleaning up third-world debt without getting taken to the cleaners.' Journal of Economic Perspectives, vol. 4(1), pp.31-42.

[8] Buchheit, Lee and G. Mitu Gulati (2000). 'Exit Consents in Sovereign Bond Exchanges', UCLA Law Review, vol. 48, pp. 59-84.

[9] Buchheit, Lee and G. Mitu Gulati (2002). 'Sovereign Bonds and the Collective Will', Working Paper No. 34. Georgetown University Law Center, Washingtion D.C.

[10] Cline, William R (2000). 'The Role of the Private Sector in Resolving Financial Crises in Emerging Markets', Mimeo, NBER Conference on Economic and Financial Crises in Emerging Market Economies, Woodstock, October 19-21, 2000.

[11] Cordella, Tito (1998). 'Can Short-term Capital Controls Promote Capital Inflows', CEPR Discussion Paper No. 2011.

[12] Diamond, Douglas and P. Dybvig (1983). 'Bank runs, Deposit Insurance, and Liquidity', Journal of Political Economy, vol. 91, pp. 401-19.

[13] Eichengreen, Barry (1999). Toward a New Financial Architecture: A Practical Post-asia Agenda, Washington, D.C: Institute for International Economics.

[14] Eichengreen, Barry and Ashoka Mody (2002). 'Bail-ins, Bail-outs and Borrowing costs', IMF First Annual Reseach Conference, pp. 155-187. 
[15] Eichengreen, Barry and Richard Portes (1995). Crisis? What crisis? Orderly workouts for Sovereign Debtors, London: CEPR.

[16] EMCA et al. (2002). 'Market-based Principles Agreed by Major Global Association', Press Release, June, 11, 2002, Washington D.C., New York and London.

[17] Fischer, Stanley (1999). 'On the Need for an International Lender of Last Resort', Journal of Economic Perspectives, vol. 13(4), pp. 85-104.

[18] Group of Ten Report (The Rey Report) (1996). The Resolution of Sovereign Liquidity Crises, Washington D.C.: IMF.

[19] Harsanyi, John and Reinhard Selten (1984). Equilibrium selection in Games, New York: John Wiley.

[20] Hellman, Thomas, K.Murdock and Joseph Stiglitz (2000). 'Liberalization, Moral Hazard in Banking and Prudential Regulation: Are Capital Requirements Enough?' American Economic Review, vol. 90(1), pp. 147-65.

[21] Jackson, Thomas A. (1986). The Logic and Limits of Bankruptcy Law, Cambridge, MA: Harvard University Press.

[22] Jeanne, Olivier. (2001). 'Sovereign Debt Crises and the International Financial Architecture', Mimeo. IMF (December).

[23] Jeanne, Olivier and Jeromin Zettelmeyer (2001). 'International Bailouts, Moral Hazard and Conditionality', Economic Policy: A European Forum Vol.0(33), pp. 407-24.

[24] Kletzer, Kenneth and Brian Wright (2000). 'Sovereign Debt as Intertemporal Barter', American Economic Review, vol. 90(3), pp. 621-39.

[25] Kremer, Michael and Seema Jayachandran (2001). 'Odious Debt', Mimeo, Harvard University, (November).

[26] Krugman, Paul (1998). 'Saving Asia: It's Time to Get Radical', Fortune, 7 September, pp. 33-8.

[27] Krueger, Anne (2001). 'International Financial Architecture for 2002: A New Approach to Sovereign Debt Restructuring', Mimeo, IMF.

[28] Krueger, Anne (2002). A New Approach to Sovereign Debt Restructuring. International Monetary Fund: Washington D.C.

[29] Miller, Marcus (2002). 'Sovereign Debt Restructuring: New Articles, New Contracts or No Change?', International Economics Policy Briefs, No. PB02-3, Washington, D.C.: Institute for International Economics.

[30] Miller, Marcus and Lei Zhang (2000). 'Sovereign Liquidity Crises: The Strategic Case for a Payments Standstill', Economic Joumal, vol. 100(460), pp. 335-62. 
[31] Morris, Stephen and Hyun Song Shin (1998). 'Unique Equilibrium in a Model of SelfFulfilling Currency Attacks', American Economic Review, Vol. 88(3), pp. 587-97.

[32] Obstfeld, M and K Rogoff (1996). Foundations of International Macroeconomics. London: MIT Press.

[33] Peck, James and Karl Shell (forthcoming). 'Sunspot in a model of bank runs', Journal of Political Economy.

[34] Baird, Douglas, Robert Gertner and Randal Picker (1994). Game Theory and the Law. London: Harvard University Press.

[35] Radelet, Steven and Jeffrey Sachs (1998). 'The East Asian Financial Crisis: Diagnosis, Remedies and Prospects', Brooking Papers on Economic Activity, 1, pp. 1-90.

[36] Rodrik, Dani (1998). 'Who Needs Capital-account Convertibility', In P. Kenen et al. (1998). Should the IMF pursue capital-account convertibility? Essays in International Finance, No. 201 (May), Princeton University.

[37] Rogoff, Kenneth and Jeromin Zettelmeyer (2002). 'Early ideas on Sovereign Bankruptcy: A Survey', IMF Working Paper, No. 57, Washington, D.C.

[38] Rogoff, Kenneth (1999) 'International Institutions for Reducing Global Financial Instability', Joumal of Economic Perspectives, Vol. 13(4), pp. 24-42.

[39] Sachs, Jeffrey (1995). 'Do We Need an International Lender of Last Resort?', mimeo, Princeton University.

[40] Schwarcz, (2000). 'Sovereign Debt Restructuring: A Bankruptcy Reorganization Approach', Cornell Law Review 85(4), 956-1034.

[41] Smalhout, J. (2001). 'Cavallo High Stakes Confidence Game', Euromoney, (May).

[42] Soros, George (1998). Crisis of Global Capitalism. New York: Public Affairs Press.

[43] Stigltiz, Joseph (1998). 'Boats, Planes and Capital Flows', Financial Times, March 25.

[44] Stigltiz, Joseph (2002a). 'Sovereign Bankruptcy: Notes on Theoretical Framworks and Policy Analyses', Mimeo, Columbia University.

[45] Stiglitz, Joseph (2002b). Globalization and its discontents. London: Penguin Books.

[46] Taylor, John (2002). 'Sovereign Debt Restructuring: A US Perspective', Mimeo, Department of the Treasury, Washington D.C. (April).

[47] Tirole, Jean (forthcoming) International liquidity, Princeton University Press.

[48] Tobin, James (1999). 'Financial Globalization: Can National Currencies Survive?', Cowles Foundation Paper No. 985, Yale University. 
[49] Truman Edwin (2001). 'Perspectives on External Financial Crises', Mimeo. Washington D.C.: Institute for International Economics.

[50] Williamson, John (1995). 'The Management of Capital Inflows', Pensamiento Iberoamericano, (January-June).

[51] Williamson, John (1995). 'Implications of the East Asian Crisis for Debt Management', Mimeo. (Available at www.iie.com.)

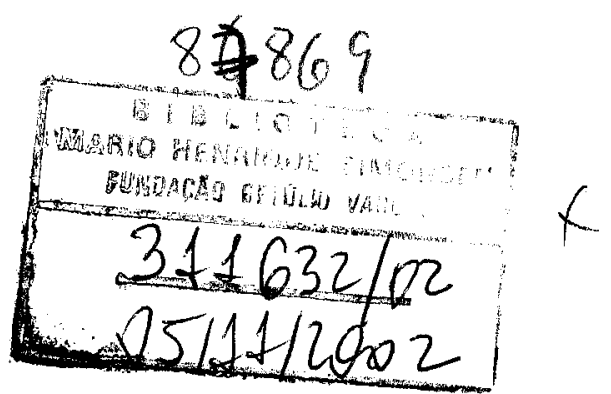


FUNDAÇÃO GETULIO VARGAS

BIBLIOTECA

ESTE VOLUME DEVE SER DEVOLVIDO Ȧ BIBLIOTECA NA ULTIMA DATA MARCADA

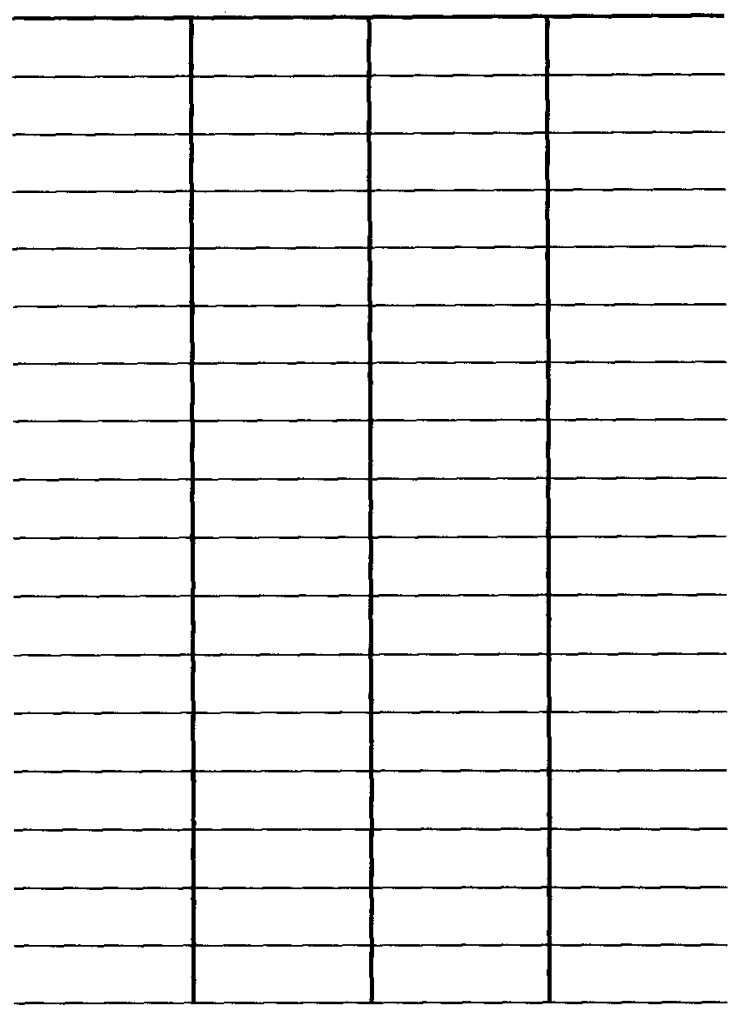

N.Cham. P/EPGE SA M649c

Autor: Miller, Marcus

Título: Co-ordination failure, moral hazard and sovereign

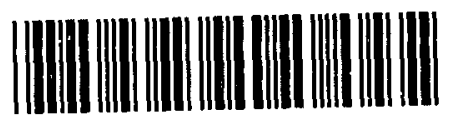

FGV - BMHS
311632

87869

$\mathrm{N}^{\circ}$ Pat: $311632 / 02$ 